\title{
The necessity of knowledge of self for proper comprehension of divine knowledge in Mulla Sadra's view
}

\author{
Ass. Prof. Rezvaneh Najafi Savad Roodbari \\ Department of Islamic Education, \\ Sistan and Baluchestan University, \\ Zahedan, Iran.
}

\begin{abstract}
:
One of the ways to know God is to acquire self-knowledge. This kind of knowledge is intuitive and in complete harmony with the soul of the mystic because it arises from the depth of our being. This kind of knowledge of God is as old as the history of mankind. There are different versions of the give and take between these two kinds of knowledge, the introduction to most of which is a comprehensive study of self and being. This paper, in an analytical way, seeks to explain the threefold narrations contained in Mulla Sadra's books. 1. Intuiting God through the intuition of the soul and the intuition of the truths of the creatures that are embodied in the active intellect. 2. Intuiting God through the connection and association of the soul with its powers and actions, and paving the process from the creative self to God as the ultimate creator, 3. Intuiting God through man's position as a caliphate and that the caliphate is a sign of the believer. This kind of self-reflection has two consequences: intuitive knowledge of the presence of God and the limited knowledge of the existence and qualities of God, not his essence. Summarizing Mulla Sadra's narrations in relation to knowing God through self-knowledge and associating Sadra's analysis and interpretations with the knowledge of the presence of God are the main findings of the present study.
\end{abstract}

Keywords: Intuition of the soul, Self-efficacy, Necessity, Intuiting God.

\section{Introduction :}

Self-knowledge is one of the important topics of human studies; this topic has been constantly addressed in religious texts that Islamic philosophers and intellectuals have worked on. According to philosophers, man is a two-dimensional entity whose physical dimension is obvious to all; however, there is another dimension of being, to which we refer when we use the word "I", a component which could be neither analyzed nor anatomized. It is located outside 
the body; we even attribute to it not only the whole body and its components, but also all its powers and feelings and perceptions: hearing, knowledge, love, and body of an individual. In all its inner powers and appearance, "I" is a manifestation; therefore, I am an unbreakable truth that cannot be neglected (Motahari, 2000: 702, 705) "I" has a continuous existence, stretching from childhood, during which this component is quite delicate and week, all through teenage years and adulthood, where this component experiences considerable rational growth. It becomes an inseparable component of being from which no break wound be possible (Tabatabai, 389). Several philosophers have been quoted in regard with the importance of the history of self-knowledge; even some philosophical schools have been founded on the basis of self-knowledge. Their motto is to make oneself aware of the world. (See also: Motahhari, 2000: 354). In Islamic texts, it has also been emphasized that the knowledge of the soul has been counted as the end of wisdom and the knowledge of God.

However, the present study will focus on the recognition of God through the knowledge of the soul, a necessary process which is quite clearly reflected in a hadith by Imam Ali (PBUH), where he says, "he who knows himself, knows the truth of his God" (Mesbah al-Shariah, 1400/13). This hadith has been explained by the interpretation of the great Islamic philosopher, Sadr al-Mota'alalin. Mulla Sadra is one of the philosophers working on this issue in his works. While he is a great philosopher, he is a great commentator on the Holy Qur'an; he is an excellent interpreter who uses his philosophical system to interpret and the teachings of religion and tries to confirm his findings by relying on religious texts.

This hadith, with an exceptional analogy, leads to the recognition of God through the process of self-knowledge. Islamic philosophers refer to the process of acquiring the knowledge of God through the perception of the soul as 'sings of self', in contrast to the verses in which man views God through the study of beings and entities. This term is derived from the Holy Qur'an. The Quran says in this regard; "We will soon show their signs around the world and within their lives to make it clear to them that he is the True; is it not enough that your Lord is a witness to everything? (Fussilat)."

The present study will try to explain how Mulla Sadra understands God in his descriptions of God's knowledge, and the result of all the narrations is that if man manages his own intuition, he will achieve a proper, and fit to his intellect, recognition of God's grandeur and beauty. 
So, before explaining Mulla Sadra's exegesis and interpretations, it seems necessary to explain a few things, the understanding of which is essential for providing a justified comprehension of Mulla Sadra's statements.

\section{Subjective interpretation}

Some followers of Mulla Sadra's school have provided three interpretations of subjective interpretation, two of which refer to macrocosmic interpretations. If the Qur'anic verses are interpreted showing human beings contemplating his nature, attributes, and actions and coming to the conclusion he is a creature of pure need because no entity has the possibility of independence, then on the one hand, external causes are supposed to necessitate such needs in him and, on the other hand, other factors eliminate the need for him; therefore, he sees himself needing God. There is another dimension to subjective interpretations through which God could be understood, namely the search and analysis of the order and relations of the components in the body and the coordination of the organs and functions of each member. This kind of interpretation, which is the proof of order, is acquired knowledge. In this narrative, the soul is counted as one of the dimensions of macrocosmic interpretation, with the difference being the fact that macrocosmic interpretations are related to the outside world and subjective interpretations are related to the inside world. But there is a third dimension to the knowledge of God through subjective interpretation which relies, primarily, on the knowledge of presence. The way of studying the acquired knowledge is through the arrangement of the preliminaries and the transfer of concepts, but in the knowledge of presence it is known that the path to reaching the knowledge of the presence is through reflection and contemplation (Javadi Amoli, 2004: 53-54)

The interpretation of Qur'anic verses into subjective and macrocosmic interpretations in verse 53 of fussilat surah implies the difference in quests and journeys, because there are two ways; therefore, the product must be two things; the knowledge deriving from subjective interpretation is acquired and that of the macrocosmic interpretation is of present type. Therefore, if one accepts the first two dimensions of subjective interpretations, all the paths will lead to the macrocosmic interpretations, and the classifications done in verse 53 of Fussilat surah will seem poorly justified, with the difference being that one focuses on the creatures of the system of creation, and another is the reflection on the particular wonders of mankind; in this case, this question arises; if all the ways of knowing God lead to a path, why self-knowledge is so valuable in Religious texts? What is the difference between knowing God through the order and wonders 
of the creatures of the universe and the recognition of God through the knowledge of the soul and why is his understanding recognized as God and the best of all, and ultimately of wisdom, and the unbelievers of God have caused selflessness? "Do not be like those who have forgotten God, and God has forgotten their truth." (Al-Hashr, 19). Hence, the pathway is an independent path, so that if we know the soul, we can know God. In this type of knowledge, the soul finds itself in the presence of God, in which case the path is one and is the most useful knowledge. Therefore, subjective and macrocosmic interpretations are two different categories with two quite distinct paths. Therefore, in the words of religious leaders, the recognition of the soul is the best and most valuable way. "Recognizing the Self is the Most Valuable." (Amadi, 712). "Everyone who knows his own soul has ultimately reached every possible aspect of knowledge of the universe." (ibid, 232).

\section{Knowledge :}

Knowledge is of two types: representational and presential. In presential knowledge, the present being is known to the world, a fact which is not applicable to representational knowledge, and the world becomes aware of it through the forms and concepts of the mind. (Motahari, 2000: 282)

In regard with subjective interpretation of Qur'anic verses, it must be stated that subjective and macrocosmic interpretations use two quite distinct paths. Representational knowledge is the fruit of macrocosmic interpretations which is realized through analyzing the present from the perspective of the concept; however, subjective interpretation has quite a different result; namely, the acquisition of presential knowledge which necessitates the unity of the present and the all-knowing. In general, representational knowledge is achieved from the passage through the heart of macrocosmic interpretation; therefore, there are two paths and there must be, accordingly, two results and two different types of knowledge. Therefore, knowledge of self leads to the knowledge of God, which is a purely presential category; i.e. there is an undeniable necessity between presential knowledge of self and God and whoever finds the truth of his being, will find the truth of God's grandeur.

\section{Which stage of knowledge of self-necessitates knowledge of God?}

The third issue to be considered in the discussion of the process of self-knowledge and recognition of God is that knowing which degree of self depends on God's knowledge. It was noted in the introduction that the soul is a continuous existence with artifacts that began from the vegetative and animal level to the highest level of 
humanity that perishes in the essence of the truth; hut which level of the soul leads to the knowledge of God? Is a child or an individual whose scientific aspects of existence have not been activated yet capable of acquiring knowledge of God or is the recognition of the superiority of the soul that has overgrown the dominance of imagination and reached the rational level and has become a true mirror of attributes of perfection and the manifestation of God's names necessary for knowing God?

According to Mulla Sadra, when the soul reaches the level of pure reason and is connected with the active intellect, the two get united; at this time, all the perfections of the entities of the world system are manifested in his own soul. This stage of magnitude is when the soul of an individual becomes capable of witnessing God's grandeur. (Shirazi, 1981:421)

\section{Knowledge of God}

Another issue concerning the knowledge of God through the knowledge of the soul must be explication and description in knowledge. Is the knowledge of God which is acquired through the knowledge of self-something detailed or cursory? In other words, does knowledge of the nature of the soul lead to the recognition of the essence of the Lord, and the recognition of the qualities of the soul require the recognition of the properties of God? Or does simple recognition of the nature and characteristics of man provide cursory knowledge of the essence of God?

All mystics and philosophers believe that it is simply impossible to know the true essence of God. Everyone has been discouraged from contemplating and thinking about the truth of the nature of God. He is too great to be accommodated within the limited mentality of human beings. (Shirazi, 1973:306)

Based on what has been stated so far, if Sadra's statements are interpreted as if there is a necessary relationship between the cognition of the soul and the knowledge of God, such a knowledge will be subjective representation and limited to names and attributes of God, because true nature of God stands beyond human recognition and knowledge, something which is likely to occur in the highest levels of the knowledge of the self.

\section{Knowledge of self and knowledge of God}

Different interpretations and explanations regarding the purpose of knowledge of the soul and the knowledge of God have been presented, mostly relying on this hadith; he who knows himself rightly, knows God. 
A. Denying interpretations, according to which it is sometime possible, and other times impossible, to gain a proper recognition of God through knowledge of the self. (Tabatabai, 1993: 170; Hassanzadeh Amoli, 2006: 28)

B. Supportive interpretations: Considering the subject matter of the article, this section will focus on supportive interpretations provided by Mulla Sadra in his book. In the narrations cited by Mulla Sadra, we are looking at what is the relationship between the knowledge of the soul and the knowledge of God. And the knowledge that comes from this purpose is either representational or presential. A close analysis of Mulla Sadra's views yield three interpretations, all of which emphasize a necessary relationship between mankind and God; knowledge of self is necessary for gaining a proper understanding of the magnitude of God's grandeur.

According to some of these interpretations, Sadra considers knowing God through the knowledge of the soul as representational knowledge, as in the first and second passages; however, it is necessary to make it clear that all beings are manifestations of God's will, dignity, and grandeur. Creatures are signs of God's grandeur because the only value they have is in the thing they represent. Self is a sign of God, a quality which makes it quite valuable. Creatures, and human soul in particular, function like mirror; you cannot look into them and not see the source which they reflected.

"All the truths of dignity, shadows and manifestations of the transcendence are not independent entities, and are not conceivable apart from the essence of God. Intuition of beings is not possible without recognizing God". (Shirazi, 1981:47)

With this interpretation of the soul and according to the second one, the meaning of the soul in the knowledge of God about the knowledge of the soul is an excellent level of perfection of the soul. If a person observes his own self, then he is also the owner of the dignity enabling him to witness God in the mirror of his soul. If some of Mulla Sadra's words appear to be that knowledge of God through the knowledge of the soul is representational knowledge, such a situation, according to the above stated material, must be interpreted as presential knowledge.

\section{The first interpretation}

On his way to perfection, man paves a process involving moving from theoretical intellect of the wisdom of the Giovanni to the wisdom of practical intellect, from the refinement of appearance to the stage of mortality, and finally to the active intellect; then, he is united with the creator and the supreme intellect and he will become a circle through which the whole microcosm of universe (ibid, 2003: 403). If 
the human soul reaches this stage, it initially witnesses the world in its own soul, and intuits God through this intuition.

"The soul is the place of the gathering of all beings; it is to everyone who knows the soul, he knows all the beings; therefore, the Lord has said; you do not think in your own self" (Room, 8).

In another occasion, it is stated that "Everyone knows the soul, knows the world, and everyone who knows the world sees God" (ibid., 131/134).

In his view, the universe is the mirror of God's beauty, when the human soul is connected to the active intellect, it sees the facts in the active intellect. Based on the argument of a reasonable union, the soul unites with those facts. In this case, the soul of man becomes the assembly of beings. He turns into a world in which all perfections of the universe are encapsulated in a simple way. Thus, knowing oneself equals knowing God, and since soul is manifestation of God's power, if one knows oneself, he becomes quite capable of knowing God.

According to Mulla Sadra, if one knows the soul, he knows the world, and if he sees the world, He will see God. By universe, he means a world that has emerged through the connection of the active intellect in the soul; if one knows the soul, since the soul is united with the forms in it, he would come to know God; therefore, the soul and whatever property it might have become mirrors for the grandeur of God; in this case, when man sees himself, he actually sees God.

\section{The second interpretation}

Actions and attributes of men are in close association with his soul; Sadra believes that the relationship of the soul with its power is manifestation of God's grandeur.

This has the power to dominate the laws of nature in the course of movement towards perfection and stepping into the horizon of the kingdom of God. When he ascends the horizons of the matter and rises from the horizon of the kingdom, one can become one with whatever element active in the universe. He can actually integrate with every other being in order to represent a full comprehension, resulting from unity of soul with God.

According to Sadra, understanding the essence and the act of the soul is the ladder of the knowledge of the essence and action of God. When the practical and theoretical power reach their perfection and the soul gets united with the active intellect, it reaches the stage of mortality, and perfection and creativity, in true sense, become quite accessible. From the point of view of the capture of the soul in the self-verbal forces of the self, the creativity of the soul permeates itself. Thus, intuition comes from the creative soul, resulting from connecting with God, because one realizes that what he does is 
actually intrigued by God, and the breath and the issuance of verbs from the soul are examples of the essence, traits, and actions of God. (ibid 1981:37)

The study of self-actualization reflects the various ways in which a person's agency is realized; in comparison with his mental images, man is a willing agent and in comparison with action arising from the mere knowledge of the individual, the subjectivity of man is more solid; in comparison with actions involving movement, man is an intentional subject and in comparison with actions which are causes by the stimulation of the soul, the position of the subjectivity of man is representational. So, self-affirmation can be considered as an example of a causative agent.

When the soul sees its creativity at the face of actions, it classifies this form of creativity and performance as belonging to the presential category of knowledge; on the one hand, soul is a sign of God and a creative soul is the best mirror for reflecting the grandeur of God, indicating the magnitude on God's action on a larger scale.

\section{The third interpretation}

Mulla Sadra presents another interpretation. According to him, man is God's caliph on the earth and a system in which all mysteries and beauties of creation is represented. Man is God's caliph and a mirror to reflect God's beauty, power, and grandeur. Individual human beings are pregnant with this attribute and, as philosophers and religious scholars believe, man is created in the same form as God. (Ibn Arabi: 120)

As a caliph of God, man is the manifestation of all the names of God, so his soul is the right of the truth, because the truth of the mirror is nothing, other than the sign of the face, the only thing that is evident in the mirror is the face of the agent; therefore, if anyone knows his own self, he knows God. "The caliph of God is the mirror that the name of God appears in him, and through him the form of all things is seen" (Shirazi, 1983:32).

"The caliph is a human being through whom all beings are seen and settled and God manifests itself in all names in him. Therefore, everyone who knows his own soul knows the truth of God. "(Shirazi, 1981:21)

According to Mulla Sadra, the position of caliphate is based on the very nature of human beings and does not require the human being to be, in mystic terms, perfect. "Man is the manifestation of God's great names and this makes him a caliph on the earth" (Shirazi, 696). The caliphate is related to the type of man, and the main criteria of his caliphate include his comprehensiveness and self-realization, although this integrity is at the potential level. As stated in the third issue, in a 
rational way, man turns to the potential of power and transforms it into a comprehensive human perfection, and this aggregation leads to his position as a caliphate; in order to become a caliph, man must have prerequisite and rudimentary goodness of nature which is quite necessary.

According to this interpretation, the intuitive agent, as the caliph of God, becomes a mirror through which God can be understood. The human soul is the mirror of God's full image. God manifests itself in the mirror of the existence of a perfect man and his caliph; when man finds himself by intuition, he can find God by intuition as well, because he is the caliph of God and the omnipresent representative of Lord's perfection; his intuition reflects God's presence and leads to the recognition of God; In fact, comprehending one's souls is the same as finding God's full image and there is no negating duality here.

According to Mulla Sadra, verse 31 of The Cow surah refers to the knowledge of God and the quality of the emergence of man as the caliphate on earth. Man is the only creature capable of manifestation of the attributes of God (ibid, 128); "I will determine a caliph on the earth" (31, The Cow)

Therefore, there is no intermediary element between the knowledge of self and the recognition of God in the three interpretations just presented; rather, all interpretations support the harmony and unity between the knowledge of self and the recognition of God.

The beautiful story of Shahid Motahari, who is himself a commentator of Sadr's school, expressed in the interpretation of the verse "Zar" states that the intuition of the soul is the same as witnessing the grandeur of God; there is no form of duality, but a distinct unity and harmony.

"God is so close to mankind, knowledge of self is so intermingled with recognition of God, self-knowledge and theology are so deeply intertwined that if one sees himself, he actually sees God and if he comes to understand himself, he has actually recognized God in all beauty and power; these two dimensions of knowledge are so close that achieving one guarantees the fulfillment of the other. Some have categorized this knowledge in two distinct groups; but, according to the Holy Quran, the knowledge of self is enough, because if one achieves this category, the knowledge of God will, automatically, come by. The unity of the knowledge of self and knowledge of God is like looking into a mirror; if you look into the mirror, you cannot help seeing the face from which the reflection is made into the mirror. "(Motahari, 1998: 354) 


\section{Conclusion :}

Based on what was stated above, it can be concluded that the recognition of God is achieved through the knowledge of self. Recognizing the existence of God through the knowledge of the soul is one of the two ways which are constantly referred to as subjective interpretation.

Three interpretations of Mulla Sadra were made in regard with the necessary connection between the knowledge of self and the knowledge of God. According to the first interpretation, the unity between soul and the active intellect and the reflection of the truths of creation within the body of man causes the revelation of the knowledge of God; according to the second interpretation, the creativity of the soul in regard with its actions and potentials established the unified bond between the soul and the creative Lord of the universe; finally, according to the third interpretation, man's position as God's caliph on the earth and the comprehensiveness of his being a mirror for God's existence become channels for the recognition of God. It must be noted that these three interpretations were based on subjective verses and interpretations.

\section{References :}

1. The Holy Quran.

2. Amidi, Abdul Wahid ibn Muhammad. (1990). Gharar al-Hakam and Radr al-Kalam. The Islamic Publications. Second edition

3. Ibn Arabi. Maki Conquests. Dar al-Asadar Publishing, Beirut, First Version.

4. Hassanzadeh Amoli, Hassan, Ayoun Mesaleh Alnafs and Shah alAyoun Fi, Al-Ayoun, Amir Kabir Publication, Second Edition, 2006.

5. Javadi Amoli Abdullah. Unity in the Holy Quran. First Printing, Qom, Asra Publishing Center. 2004.

6. Shirazi Sadr al-Motaalain, Mohammad. Al-Hakma al-Metaliyah fi Esfar al-Ra'bah. Third edition, Darahi'a al-'Arat al-Arabi, Beirut, $1981 \mathrm{~m}$.

7. Asrar Al-Ayat. Introduction and definition by Mohammad Khwajawi. The Society of Wisdom and Philosophy, 1981.

8. Mofatih al-Ghaib. Corrected by Mohammad Khwajawi, Tehran Cultural Research Printing House, 1984.

9. Evidence of Al-Sabbayah, Corrected by Seyyed Jalaluddin Ashtiani, Tehran Cultural Research Printing House, 1981. 
10.Al-Mizahar al-Allahieh Fi Asrar al-ulum al-Malayyah, Sadra Islamic Society Publication, Tehran, first edition, 1999.

11.The interpretation of the Holy Quran. Qom Bidar Publication. Second edition, 1986.

12.Al-Mobda and al-Maad. Society of Wisdom and Philosophy of Iran, Tehran, First Printing, 1975.

13.A commentary on Kafi Principles. Institute of Humanities and Cultural Studies Publication. Second edition, 2004.

14.Tabataba'i, Mohammad Hussein. The Collection of Booklets. Qom Boostan Publication. First edition. 2008.

15.Al-Mizan Fi Tafisr al-Quran. Ismaelian Publication. Qom: second edition. 1992.

16.Qunwi Sadr al-Din. Muftah al-Ghaib, Dar-e-Qab al-Almaya, Beirut, 1st edition, 2010.

17.Mesbah Al-Shariah, attributed to Imam Sadiq (AS), Alaami Institute, Beirut, First Printing, 2018.

18. Motahari Morteza, Collection of Works, Sadra Publication, Qom, 2009.

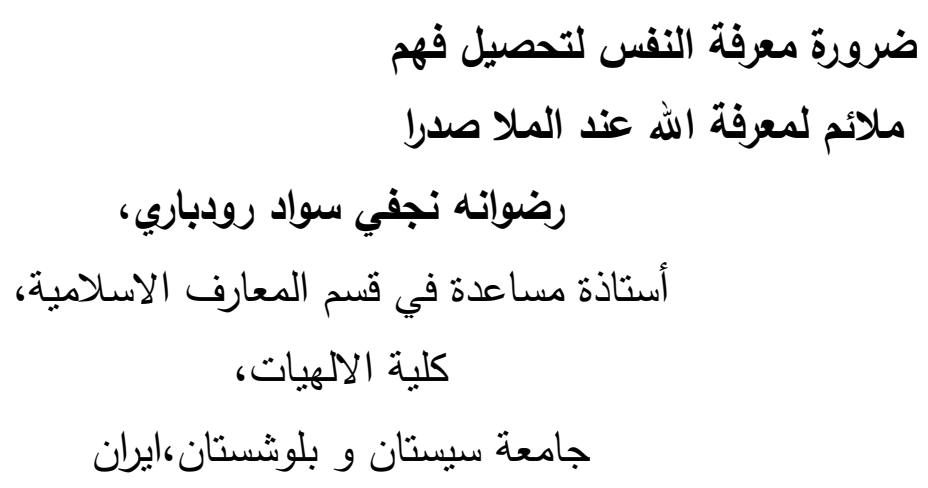

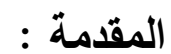

احدى طرائق معرفة الله هي معرفة النفس. هذا النوع من المعرفة بديهي وفي انسجام

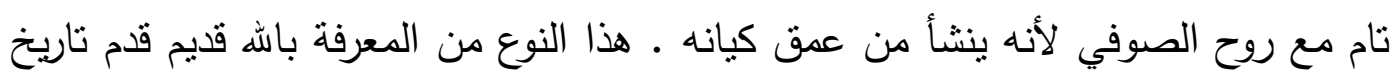

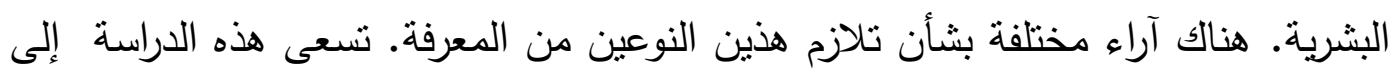

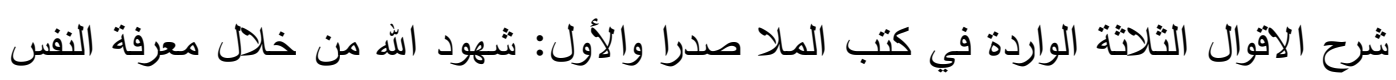
وحقائق المخلوقات التي تتجسد في الذهن الفعال والقول الثاني: شهود الله من خلال الارتباط وتتسيق النفس مع القوى وأفعال الثخص ، والوصول من النفس الخلاقة إلى الله الخلاقة 
Al-Adab Journal - Plus No. 126 (September) 2018 / 1439

والقول الثالث: أنَّ هذه المعرفة تأني من خلال وضع الإنسان بصفته خليفة ، إذ الخليفة هو آية الدستخلف.تتتنج نتيجتان لهذا النوع من النظرة الى النفس : العرفة البديهية لوجود الله

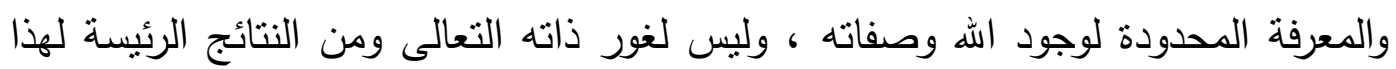
البحث الاتيان بتلخيص آراء ملاصدرا بشأن موضوع معرفة باله من خلال معرفة النفس وتمد تصوراته وأفكاره مصاديق العلم الحضوري في هذا الجانب.

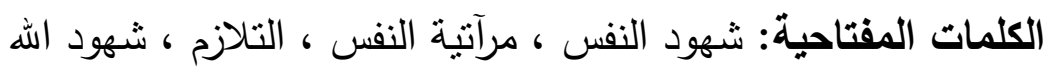

